\title{
MODEL ARSITEKTUR ENTERPRISE MENGGUNAKAN ENTERPRISE ARCHITECTURE PLANNING (EAP)
}

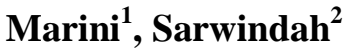 \\ ${ }^{1,2}$ Jurusan Sistem Informasi Prodi Sistem Informasi STMIK ATMA LUHUR \\ Jln. Jend. Sudirman - Selindung Lama Pangkalpinang \\ 1 arinimarini44@atmaluhur.ac.id \\ 2indah_syifa@atmaluhur.ac.id
}

\begin{abstract}
Abstrak - Akademi Abdi Nusa pangkalpinang merupakan sistem informasi yang bergerak dibidang pendidikan kesehatan. Dengan adanya sistem interprise ini maka akan mendukung perencanaan sistem informasi yang baik dan teratur. Perencanaan sistem informasi yang masih kurang baik mengakibatlan kurang terarah prosedur sistem informasi pada Akademi tersebut. Maka dari itu penulis akan merancang sistem blue print pada Akademi. Sistem enterprise Architecture Planning (EAP) yaitu penataan operasi pengertian dari penataankepada pemakian informasi untuk menunjang kegiatan, penataan untuk penerapan penataan sistem. Dipaper ini memaparkan tentang penataan arsitektur informasi pada organisasi, Akademi, sistem informasi ini saling berhubungan antar bagian supaya untuk mempermudah dalam mendapatkan informasi. Model yang dibangun ini bertujuan diharapkan pengembangan sistem informasi dimasa yang akan datang. Penelitian ini penulis akan mengkaji penerapan model sistem informasi architecture Planning pada Akbid Abdi Nusa pangkalpinang dengan menggunakan konsep blue print diantaranya architectur data,aplikasi dan teknologi. sistem informasi Akademik ini diawali tahap menganalisa kegiatan akademik dan strategi kegiatan pendidikan
\end{abstract}

Kata kunci-Sistem, Informasi, Sistem Interprise, Architectur, Blue Print

\section{Pendahuluan}

Peralatan yang dipakai dalam memperoleh informasi yaitu penahan pelindung pusat meliputi semua alat yang digunakan dipaki untuk mengolah dan mengirimkan data[1]. Perkembangan peralatan sekarang ini meliputi beberapa bagian peralatan sekarang ini, peralatan suara. Peralatan suara antara lain semua yang berhubungan pengolahan data, pemakaian pelindung, perubahan dan diolah data. Peralatan suara adalah semua yang berhubungan pemakaian peralatan suara sebagai pendukung melakukan pengolahan dan mengirimkan informasi beberapa perangkat yang digunakan. Maka peralatan sekarang ini dan peralatan suara antara lain beberapa bagian yang punya kesamaan. Peralatan pusat data dan peralatan suara terdapat arti yang sangat luas adalah semua aktivitas yang saling berhubungan dalam mengolah data, perubahan data, diolah, transfer data ke peralatan lainnya. Datang TIK penggabungan antara peralatan suara dan peralatan komputer (peralatan yang bisa dirasa dan peralatan yang tidak bisa dirasa ) pada peralatan suara di peradaban sekarang ini. Penggadengan peralatan suara pada zaman sekarang semangkin pesat persaingannya.

Arsitektur Interprise pada aplikasi yang terintegrasi merupakan sebuah proses penyelenggaraan pendidikan yang berhubungan langsung dengan mahasiswa tersebut, dan juga sangat dibutuhkan dalam kegiatan akademik juga termasuk kebagian akademik. Bagian Akdemik adalah terdiri dari beberapa bagian dan progres kependidikan serta perencanaan yang diterapkan untuk memberikan pertolongan yang sangat maksimal pada perubahan aplikasi. Sedangkan Pengembangan akademik merupakan salah satu teknik atau layanan didalam Pendidikan terutama bagian akademik, tetapi teknik atau layanan ini sangat istimewa karena sifatnya yang lentur. Bagian Akademik ini juga bertugas untuk membantu mahasiswa dalam hal akademik, mengenal Pengisian Krs, Bimbingan Skripsi, Penilaian dan Laporan Pengajaran bagi dosen, serta menyusun rencana untuk mencapai tujuan-tujuan itu, dan bagian akademik ini juga mengatasi Perkuliahan mahasiswa. Maka dengan adanya Model system Interprise ini sangat berperan penting terhadap mahasiswa, staf, dosen, agar memanfaatkan sistem ini dengan lebih baik lagi. 
Kegunaan peralatan yang berhubungan dengan peralatan aplikasi untuk media aktivitas pendidikan di negara ini sudah memyebar luas dan memiliki peranan penting dalam jangka sangat jauh sekali. Dengan adanya perubahan penyebaran informasi tentang pendidikan melalui media komunikasi tentang pendidikan serta ke beberapa daerah untuk mendapatkan informasi ke seluruh dunia. Maka dari ini perubahan untuk mengefisiensi penggunaan peralatan untuk mempermudah dalam kegiatan belajarmengajar. Adapun kelemahan dari peralatan media komunikasi untuk melakukan penyebaran informasi akan ada timbal balik yang. Peralatan data dan informasi akan melakukan aktivitas yang sangat berguna untuk merubah relasi aktivitas ini. Peralatan komunikasi dengan daerah yang tidak bisa dijangkau akan lebih cepat dilakukan. pada kemajuan perubahan bagian aktivitas akademik sangat dibutuhkan penataan Sistem Informasi Enterprise Architecture dalam menghubungakan setiap bagian pada aktivitas kegiatan bagian sistem informasi dan perencanaan untuk perusahaan yang disupport dengan peralatan teknologi untuk kegiatan akademik perguruan tinggi penataan Enterprise Architecture mendukung kegiatan bagian akademik dan melakukan perbaharui keaplikasi yang saling berhubungan antar bagian.

Enterprise architecture planning adalah pengarahan dalam perencanaan mutu didukung berdasarkan keperluan aktivitas sampai ke uji coba ke perencanaan penataan yang desain untuk mengsupport ke sasaran yang ingin dicapai pada sistem informasi dan perusahaan.[2].

Hal yang duluan dilakukan untuk membuat model kegiatan akademik di perguruan tinggi bisa memakai teori nine building[2]. Dalam memahami model aktivitas kegiatan setiap bagian memapatkan beberapa bagian-bagian yang sangat sakral pada kegiatan aktivitas akademik. Beberapa kegiatan aktivitas akademik bisnis dibuat dalam sebuah model notation[3]. Kemudian sangat diperlukan proses information resource catalog antara lain adalah arsip data informasi dan platform peralatan yang dipakai untuk perguruan tinggi sekarang. Information resource catalog dibutuhkan untuk mengkaji ulang untuk kegiatan akademik kepada bagianbagian informasi perguruan tinggi sekarang. Kemudian merancang penataan data dengan cara mengidentitas semua data yang dibutuhkan apa saja kegiatan akademik yang diperlukan. Maka dibuatkan entity data tersebut. Kemudian mensesuaikan bagian-bagian kegiatan akademik yang berbentuk matrik bagian kemudian membuat sub-sub bagian akademik yang sesuai dengan keadaan data yang sekarang. Keadaan aplikasi yang digunaka bisa berguna untuk memproses data secara cepat dan tepat untuk bagian -bagian yang memerlukan[4]. Bagian-bagian bisa mendapat proses perubahan secara secara baik. Pada jurnal ini akan mencoba menerapkan konsep Enterprise Architecture Planning (EAP) dalam membuat blueprint Penataan Model arsitektur enterprise pada Akbid Abdi Nusa Pangkalpinang.

\section{MEtodologi PenElitian}

Bagian ini menjelaskan secara rinci tentang penelitian yang dilakukan.

\section{A. Pemodelan Aplikasi Sistem}

Hal yang terpenting dalam merencanajan sasaran informasi yaitu perlu menyiapkan langkah-langkah dalam menganalisa proses kegiatan bisnis, merancang serta melakukan perubahan yang masih dilakukan secara manual ke perubahan aplikasi sistem komputer [5]. Metode yang dipakai untuk mengembangkan data, beberapa tahapan yang dilakukan dibeberapa agianadalah data dan kegiatan aktiviatas. Dalam merencanakan teknik analisa data, ke arah sasaran jalur pada yang memerlukan informasi enterprise[6]. Kemudian dibagian aktivitas, arah kajian strategisnya guna menggunakan peralatan aplikasi dalam meningkatkan proses kerja enterprise. Perencanaan dari metode dan Penataan Enterprise Architecture Planning adalah persiapan awal yang harus diperhatikan mengenai pemahaman mengenai Enterprise Architecture dipersiapkan masih dilakukan secara manual sehingga akan berpengaruh pada bagian framework, Model metode yang dipakai untuk hal-hal yang kerjakan dengan benar sertabagian dan pelatihan[7]. Dalam model metode penelitian ini terdiri dari beberapa tahap dalam merancang arsitektur yang ada di dalam EAP, yaitu :

a. Pengumpulan Data

b. Aktivitas Proses

c. Perencangan Model sistem dan Perangkat

d. Mmbuat Perancangan Desain Model enterprise

1) Model Data

2) Model Sistem Aplikasi

3) Model Jaringan

4) Testing

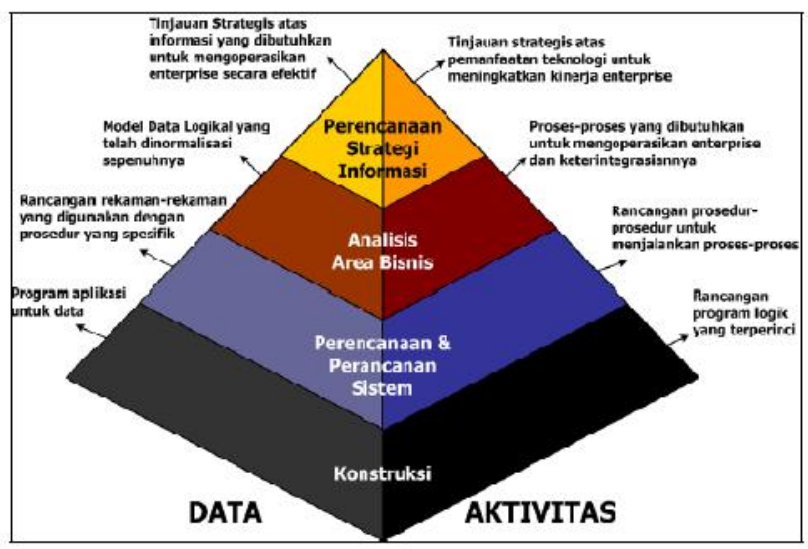

Gambar 1. Desain Model Enterprise

\section{B. Enterprise Architecture Planning}

Langkah-langkah yang dibutuhkan untuk membangun EAP (Gambar 4) yang harus dilakukan untuk mengerti kondisi sekarang, dalam pencapaian yang akan direncanakan untuk 
sesuai dengan sarasan yang ingin dituju ke kondisi yang akan datang kemudian langkah berikutnya menyesuiakan Visi dan misi Perusahaan untuk kebutuhan dimasa yang akan datang

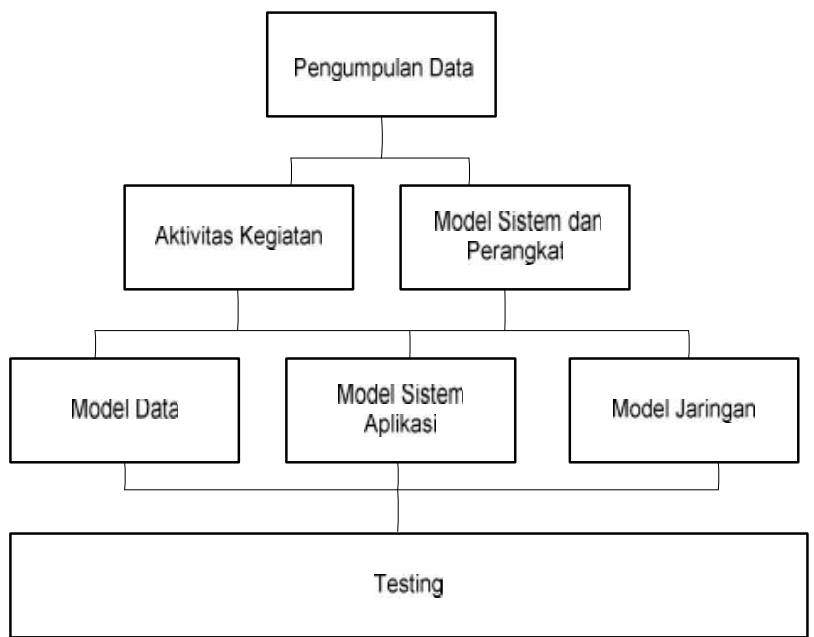

Gambar 2. Enterprise Architecture Planning

1. Pengumpulan data

Proses pengumpulan data yaitu langkah yang dilakukanuntuk memperoleh masalah-masalah yang terjadi dalam aktivitas kegiatan disetiap bagian serta pengumpulan arsi laporan seperti dokumentasi yang sangat dibutuhkan dalam pelaporan.

2. Aktivitas kegiatan

Aktivitas kegiatan mempunyai peranan penting dalam menyusun kegiatan apa saja yang dilakukan oleh setiap bagian sehingga dapap menghasilkan sebuah dokumentasi yang berhubungan dengan aktivitas tersebut

3. Model sistem dan perangkat

Model sistem yang akan digunakan dalam merancang aplikasi tersebut harus lah sesuai dengan kebutuhan aplikasi yang akan dibuat serta perangkat yang bisa mendukung berjalan operasi aplikais tersebut

4. Model data

Model data yang terdiri dari item-item yang berkaitan dengan data base aplikasi serta aktivitas kegiatan yang berhubungan dengan hasil yang dibutuhkan untuk proses pelaporan dan dokumentasi

5. Model aplikasi

Memodelkan aplikasi yang akan dibuat dalan menentukan aplikasi dan mensupport berjalannyan lingkungan aplikasi tersebut.

6. Model jaringan

Suatu medel yang akan dipakai pada aplikasi pendukung berjalannya area bagian aplikasi data

7. $\quad$ Testing
Untuk merinci perubahan dari sistem yang lama dengan sistem yang baru guna untuk melihat perbandingan dari fasilitas biaya yang akan dilkeluargan serta menguji seberapa besar manfaat dengan perubahan aplikasi yang sudah dibangun.

\section{HASIL DAN PEMBAHASAN}

Ada beberapa tahap yang dilakukan untuk memodelkan EAP dengan membuat Konsep Blueprint untuk memodelkan Perencanaan Enterprise Akbid Abdi Nusa Pangkalpinang. Tahap yang dilakukan sesuai dengan Konsep EAP antara lain :

\section{A. Pengumpula Data}

Berikut ini uraian prosedur yang dilakukan pada perencanaan yaitu : memodelkan Arsitektur Enterprise Akbid Abdi Nusa Pangkalpinang adalah sebuah instasi yang bergerak dibidang pendidikan formal di tingkat Akademi Kesehatan. Uraian proses bisnis instansi ini melayani bentuk jasa pendidikan untuk kebutuhan informasi dibidang pendidikan. Maka dari itu tujuan dari membangun sistem Aplikasi dan struktur jaringan dari EAP sangat dibutuhkan untuk mendukung proses pendidikan cakupan dan tujuan pada langkah-langkah yang saling berkaitan dengan kegiatan utam akademik : PMB, Operasional Akademik, Pelepasan Akademik.

\section{B. Aktivitas Kegiatan}

Konsep dari analisa rantai nilai (value chain) dideskripsi oleh michael porter dapat membantu dalam melakukan analisis aktivitas-aktivitas spesifik yang dapat menciptakan nilai dan keuntungan kompetitif bagi organisasi. Rantai nilai terdiridari kategori aktivitas yaitu : aktivitas utama (primary activities) dan aktivitas penunjangnya (support activities)[10]

Rantai nilai utama pada Akbid Abdi Nusa Pangkalpinang ini memiliki rantai nilai dalam proses kegiatan akademik untuk model pendidikan. Untuk proses aktivitas dapat dilihat pada gambar rantai nilai utama model pendidikan dibawah ini.

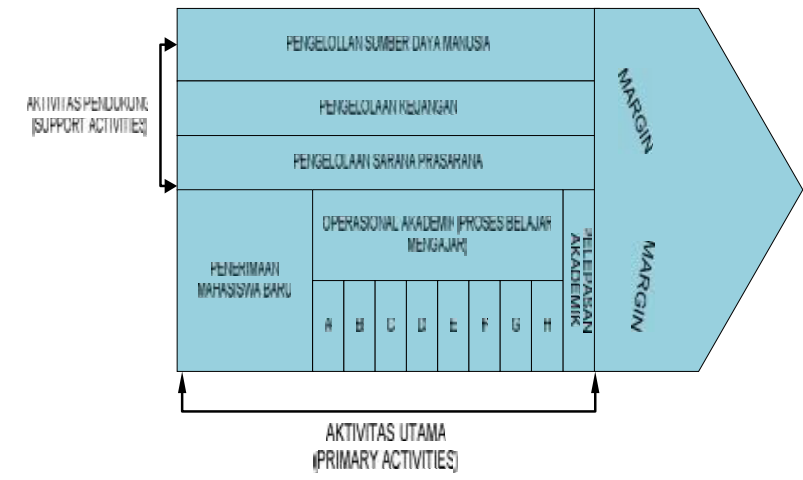

Gambar 3. Rantai Nilai Aktivitas Utama Model Akademik 
Dari gambar 3 diatas menguraikan mengenai aktivitas utama (Primary Activities) dibawah ini adalah :

1. Penerimaan Mahasiswa Baru : Mulai dari proses Mempromisikan Jurusan Program Studi yang dilakukan oleh bagian penerimaan mahasiswa baru, setalah itu dilanjutkan proses Registrasi PMB, Proses Tes, Pemberitahuan Hasil, Pemberkasan, proses pembayaran, dan registrasi ulang.

2. Operasional Akademik : Pembuatan KTM, Penentuan Matakuliah persemester, Penentuan dosen PA, Dosen Pengampu Matakuliah, KRS, KPRS, Pembayaran matakuliah, Jadwal matakuliah, Perkuliahan, Ujian semester, KHS, Laporan Berita acara Mengajar

3. Pelepasan Akademik : Transkip Nilai, Ijazah, Wisuda, Alumni.

Tahap- Tahap yang dilakukan dalam Aktivitas Model Akademik

\section{a. Aktivitas Pendukung antara lain :}

Pemberdayaan SDM : proses mengenai mulai dari biaya operasional akademik, sumber daya manusia, Rekrument pegawai, Pengendalian, pengawasan, pengontrolan, penggajian, laporan kinerja sumber daya, dan evaluasi

\section{b. Pengelolaan Keuangan :}

Kebutuhan anggaran akademik, Biaya operasional Akademik, Dana Mahasiswa yang aktif dan Pengeluaran Biaya Operasional dan pelaporan Keuangan.

\section{c. Pengelolaan Sarana dan Prasarana :}

Pengelolaan kebutuhan Sarana dan prasaran seluruh bidang akademik yayasan, Pengawasan, Pengontrolan, Dan laporan sarana dan prasarana

\section{d. Model sistem dan Perangkat}

Perkembangan Model Aplikasi dan Perangkat masa sekarang sangat memiliki peran penting untuk melihat keaadan Aplikasi yang berhubungan berkembangknya perangkat aplikasi untuk mendapatkan informasi mendirikan sebuah aplikasi sistem di Akbid Abdi Nusa Pangkalpinang. Berdasarkan pengamatan di Akbid Abdi Nusa Pangkalpinang, beberapa hal aktivitas yang berhubungan dengan aplikasi sistem dan struktur jaringan perangkat sebagai berikut :

a) Belum ada sistem informasi untuk mendukung aktivitas utama dari bisnis organisasi.

b) Penggunaan platform teknologi yang ada belum dimanfaatkan secara optimal, terlihat adanya perangkat komputer yang tidak digunakan, demikian juga dengan penggunaan perangkat lunaknya.

c) Belum adanya infrastruktur pendukung untuk sistem informasi seperti peralatan jaringan dan komunikasi data. d) Tidak adanya personil yang ahli dibidang TI menjadi faktor kendala dalam pembangunan sistem informasi.

Berdasarkan kondisi tersebut, dapat diambil kesimpulan pihak Akbid Abdi Nusa Pangkalpinang Perancangan Arsitekture Enterprise Pada Akbid Abdi Nusa Pangkalpinang. Untuk mendukung pembangunan sistem informasi tersebut perlunya dibuat suatu model arsitektur sistem informasi berbasis ICT

\section{Pembangunan Model Arsitektur Enterprise}

\section{Model data}

Arsitektur data adalah Mendefinisikan entitas yang digunakan dalam Perancangan Arsitekture Enterprise Pada Akbid Abdi Nusa Pangkalpinang ini terdiri dari beberapa data yang telah digambarkan dalam sebuah diagram ERD pada gambar 4

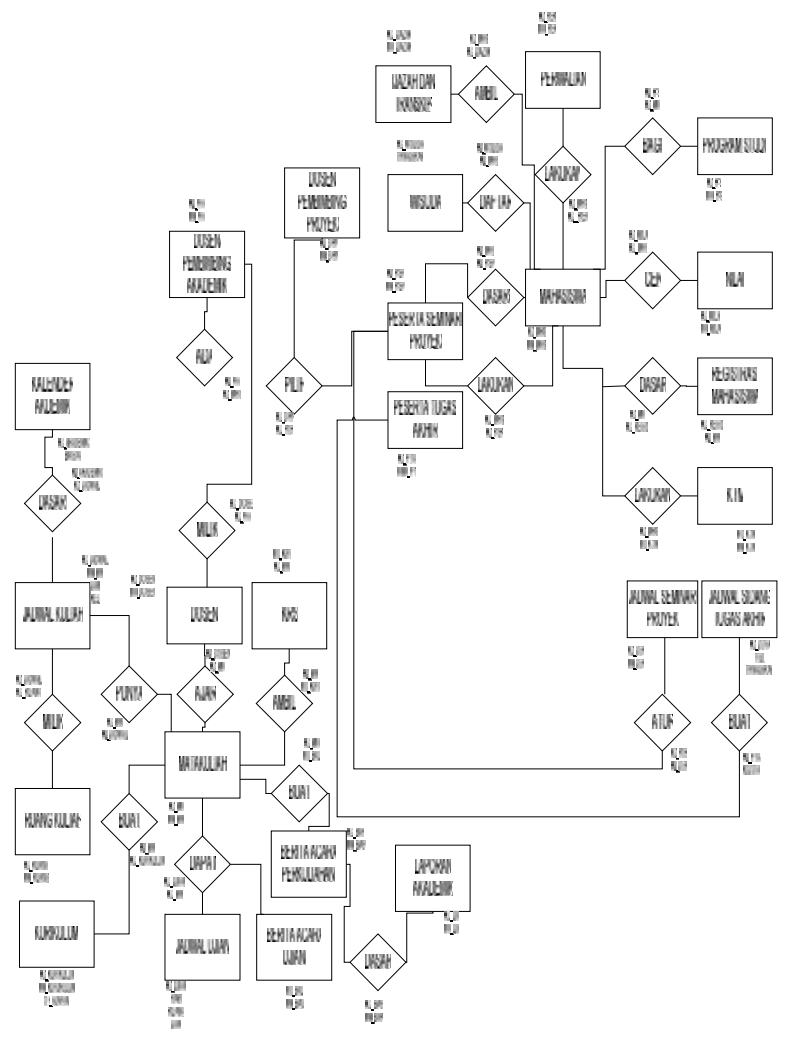

Gambar 4. ERD Data Peneriman Mahasiswa Baru, Data Proses Akademik dan Data Kelulusan Mahasiswa

Model data dalam sebuah hubungan data yang digambarkan dalam sebuah gambar Entitas set yang terdiri dari kalender akademik(atributnya : kd_ka,nm_ka), jadwal kuliah (atributnya : kd_jadwal, nm_jadwal), ruang kuliah (atributnya : kd_ruang,nm_ruang), dosen (atributnya : kd_dosen, nm_dosen) , kurikulum (atributnya : kd_kurikulum, nm_kurikulum), mata kuliah (atributnya : kd_mk, nm_mk), jadwal kuliah (atributnya : kd_jdwal, nm_jadwal), berita acara 
akademik (atributnya : kd_bak, nm_bak), berita ujian (atributnya : kd_bu, nm_bu), laporan akademik (atributnya : kd_la, nm_la), ijazah, wisuda (atributnya : kd_ijazah, nm_ijazah), atribut dan relasi yang terdapat pada pada gambar 4

\section{Model aplikasi}

Desain Model aplikasi adalah berfungsi untuk pangkal utama yang digunakan untuk mengolah aktivitas yang terjadi dalam sistem yang bertujuan untuk mendukung aktivitas dalam suatu sistem interprise. Desain aplikasi ini tidak merancang sistem tetapi mendefinisikan apa yang akan mengolah data dan menghasilkan informasi bagi penerima informasi yang berkaitan dengan bisnis.

Untuk desain arsitektur aplikasi menggunakan Application Portfolio untuk merancang yang perlukan pada aplikasi. Application Portfolio padat dilihat pada gambar dibawah ini :

Tabel 1. Matrik Portofolio Aplikasi

\begin{tabular}{|c|c|}
\hline Strategic Application & $\begin{array}{l}\text { High Potential } \\
\text { Application }\end{array}$ \\
\hline $\begin{array}{l}\text { Dana Biaya Operasional Promosi. } \\
\text { Penerimaan Mahasiswa Baru. } \\
\text { Kurikulum. } \\
\text { Pendataan Dosen. } \\
\text { Registrasi Mahasiswa. } \\
\text { Data Kepegawaian. } \\
\text { Pendidikan dan Penelitian. } \\
\text { SDM. } \\
\text { Gaji SDM. } \\
\text { Pendidikan mahasiswa. }\end{array}$ & $\begin{array}{l}\text { Proses Pendaftaran } \\
\text { dan Pembayaran } \\
\text { Mahasiswa Baru. } \\
\text { Data Pengolahan } \\
\text { Ujian Masuk Seleksi } \\
\text { Mahasiswa Baru. } \\
\text { Data Mahasiswa. } \\
\text { Data Alumni. }\end{array}$ \\
\hline $\begin{array}{l}\text { Data Kartu Rencana Studi dan } \\
\text { Kartu Mahasiswa. } \\
\text { Koreksi Rencana Studi. } \\
\text { Jadwal Perkuliahan. } \\
\text { Pendaftaran Ujian. } \\
\text { Proses seminar sidang. } \\
\text { Pembayaran seminar dan sidang. } \\
\text { Proses Nilai Akademik Mahasiswa. } \\
\text { KHS. } \\
\text { Pelaporan Akademik. } \\
\text { Ijazah dan Transkip Nilai. } \\
\text { Administrasi Wisuda. }\end{array}$ & \begin{tabular}{lr}
\multicolumn{2}{l}{ Laporan PMB } \\
Laporan SDM \\
Laporan & Seleksi \\
SDM & \\
Laporan & Kehadiran \\
SDM & \\
Laporan & Kinerja \\
Dosen & \\
Laporan & analisis \\
keuangan & \\
Laporan & penggunaan \\
sarana dan prasarana
\end{tabular} \\
\hline Key Operational Aplication & Support Application \\
\hline
\end{tabular}

Kaitan dengan aplikasi dengan entitas data dapat dirancang dalam relasi antara keduanya yang membentuk CUR matrik sedangkan untuk fungsi-fungsi bisnis dapat disupport oleh aplikasi mada dapat dirancang matrik relasi aplikasi yang saling terkait.

\section{Model Jaringan}

Arsitektur teknologi ini adalah menjadi tujuan utama dari perencanaan teknologi yang diperlukan dalam support aplikasi dalam mengatasi masalah data. Model Jaringan memiliki pengertian jenis aplikasi yang mensupport saling terhubung. Model jaringan dibuat dibawah ini adalah sistem baru untuk jaringan arsitektur di Akbid Abdi Nusa Pangkalpinang pada gambar di bawah ini.

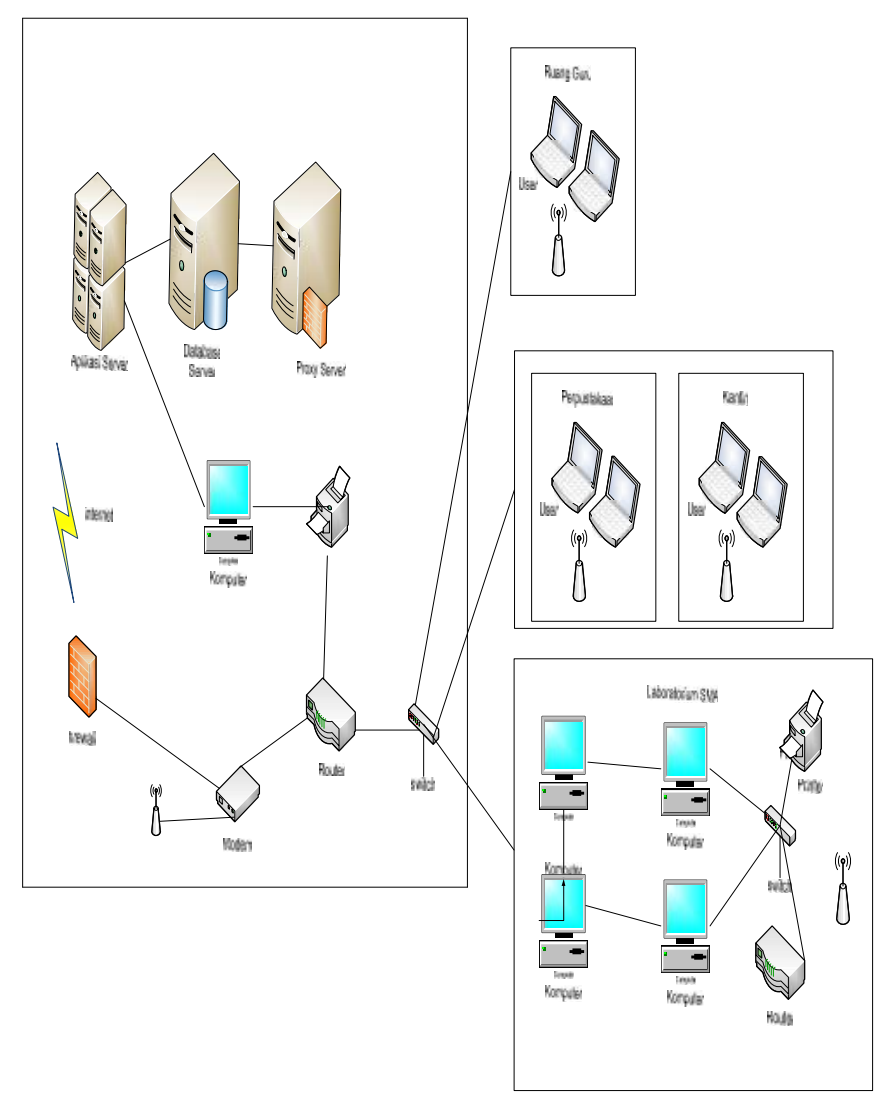

Gambar 5. Arsitektur Teknologi

\section{KESIMPULAN}

Kesimpulan yang dapat uraikan pada langkah langkah yang sudah di teliti adalah sebagai berikut : sistem blueprint dalam tahapan pengujian implementasi yang menjadi acuan pada perancangan sistem aplikasi yang dapat mensupport jalannya proses bisnis pada Perancangan Arsitekture Enterprise di Akademik, dan arsitektur data dan teknologi yang didapat dalam penelitian ini yang saling terintergrasi dan terhubung. Dengan adanya rancangan kegiatan model bisnis value chain porter akan dapat mensupport semua kegiatan akandemik. Arsitectur yang dirancang akan menentukan kegiatan akademik dimasa yang akan datang. 


\section{REFERENSI}

[1] Haryanti, Edy.(2008). Teknologi Informasi dan Komunikasi: Konsep dan Perkembangannya. Pemanfaatan Teknologi Informasi dan Komunikasi Sebagai Media Pembelajaran.

[2] Spewak Steven H., (1992). "Enterprise Architecture Planning”, John wiley \& Sons Inc,New York.

[3] Bridgeland David M. And Ron Zahavi, (2009). “ Business Process Modeling Notation”, Elsevier Inc., Burlington.

[4] Spewak, Stevan H., Hill, Steven C., (1992). Enterprise Architecture Planing: Developing a Blueprint for Data, Aplicatior, and Techology, John Wiley \& Sons.

[5] Martin, James, (1990). Information Enggineering (Book II, Planning and analysis), Prentice-Hall.

[6] Spwak Steven., and Tieman Michail. (2006). "Update The Enterprise Architecture Planing Model". Journal Of Enterprise Architecture.

[7] Supriyana, I. (2010). Model Arsitektur Bisnis, Sistem Informasi Dan Teknologi di Bakosurtanal Berbasis Togaf. Tekkomnika (Telecommunication computing dan Electronics and control),8, 17-24

[8] Yunis, R. \& Surendro, K, (2009) Perancangan Model Enterprise Architecture dengan Togaf Architecture Development Method. Jurnal Seminar Nasional Aplikasi Teknologi Informasi,.

[9] Surendro, K. (2007). Pemanfaatan Enterprise Architecture Planning Untuk Perencanaan Strategi Sistem Informasi. Jurnal Informatika, 8, Pp.1-9

[10] Triloka, Joko. (2008). Pemodelan Arsitektur untuk mendukung sistem informasi terintegrasi dibidang akademik menggunakan enterprise architecture planing. Prosiding seminar nasional sains dan teknologi II, Universitas Lampung. 